\title{
Familial Central Nervous Malignancies Focus on Spinal Meningioma: Incidence in First Degree Relative
}

\author{
Dr. Manmeet Pal Kaur ${ }^{1 *}$, Dr. Niten K Garg ${ }^{2}$, Dr. Kanika Kinra ${ }^{3}$, Dr. Venus Sharma ${ }^{1}$
}

${ }^{1}$ MBBS, Punjab Institute of Medical Sciences Jalandhar, Garha Rd, Jalandhar, Punjab 144006, India

${ }^{2}$ DNB Neurosurgery, S.G.L. Superspeciality Hospital Garha Road Jalandhar, Garha Rd, Guru Amardas Market, Hardyal Nagar, Jalandhar, Punjab 144022, India

${ }^{3}$ MBBS, 3rd Year Resident Internal Medicine, S.G.L. Superspeciality Hospital Garha Road Jalandhar, Garha Rd, Guru Amardas Market, Hardyal Nagar, Jalandhar, Punjab 144022, India

DOI: $10.36347 /$ sjmcr.2020.v08i09.015

| Received: 18.08.2020 | Accepted: 26.08.2020 | Published: 30.09 .2020

*Corresponding author: Manmeet Pal Kaur

Abstract

Case Report

Meningiomas are extramedullary, intradural tumors arising from meningothelial arachnoid cap cells within the spinal dura. Spinal meningiomas are the most common spinal tumors in adults, accounting for up to $38 \%$ of intradural spinal tumors but only for $6.5 \%$ of overall craniospinal tumors in the adult age group. Similar histological subtypes are observed in both intracranial and spinal meningiomas, including meningothelial, metaplastic, psammomatous, transitional, atypical, and clear cell types. Multiple genes have been associated with spinal meningiomas like deletion of chromosome 22q and of its associated gene NF2 in cases of spinal meningioma. We are presenting a case of Intradural meningioma in a 30 year old female and her 50 year old mother.

Keywords: Meningiomas, meningothelial, metaplastic, psammomatous.

Copyright @ 2020: This is an open-access article distributed under the terms of the Creative Commons Attribution license which permits unrestricted use, distribution, and reproduction in any medium for non-commercial use (NonCommercial, or CC-BY-NC) provided the original author and source are credited.

\section{INTRODUCTION}

Spinal meningiomas usually occur after the fourth decade of life, over $70 \%$ of the patients are between the ages of 40 and 70 years with a mean age of 50 years, with similar frequency as the nerve sheath tumors, representing approximately $25 \%$ of all spinal cord tumors, $40 \%$ of intradural extramedullary tumors, without invading pia mater [1-8]. Most meningiomas have a significant predilection for females $75 \%-85 \%$ of cases; arising primarily in the thoracic region approximately $80 \%$; the cervical region is affected less often; lumbar and sacral tumors are relatively rare [9]. Meningiomas typically grow slowly and usually with benign character, with a region of dural attachment, often seen dorsal-lateral, in a globoid configuration; rarely "en plaque meningiomas" - as a carpetlike [10, 11]. Clinical findings vary from mild to significant neurologic dysfunction; the most frequent clinical findings are back pain, sensori-motor deficit and sphincter dysfunction [9].

\section{Case Report}

30 year old female presented with the history of lower back pain radiating down to both legs, numbness and weakness in both legs with loss of sensation of touch, and temperature variations since 3 months, and difficulty maintaining balance which was progressive for 2 months. On examination, patient had spastic paraparesis of bilateral lower limb with power 2/5. MRI revealed D9-D10 intradural tumor of spine. D9-D10 laminectomy with gross total excision of tumor was done which revealed firm/hard tumor densely attached with dura and surrounding nerve roots. The patient showed some improvement in her neurological deficits after surgery and was discharged after 1 week with close follow up.

5 years ago, the patient's 50 year old mother had similar symptoms of weakness in both legs which progressively worsened. On examination, patient had spastic paraparesis of bilateral lower limb with power 2/5. MRI showed D4-D5 intradural extramedullary lesion in left lateral thecal sac with dural enhancement. D4-D5 laminectomy with partial excision of tumor was done. Histo-pathology showed meningo-theliomatous meningioma (WHO grade-1). Patient was discharged in stable condition with slight improvement in the neurological deficits. Follow up showed substantial improvement in the patient's weakness. 

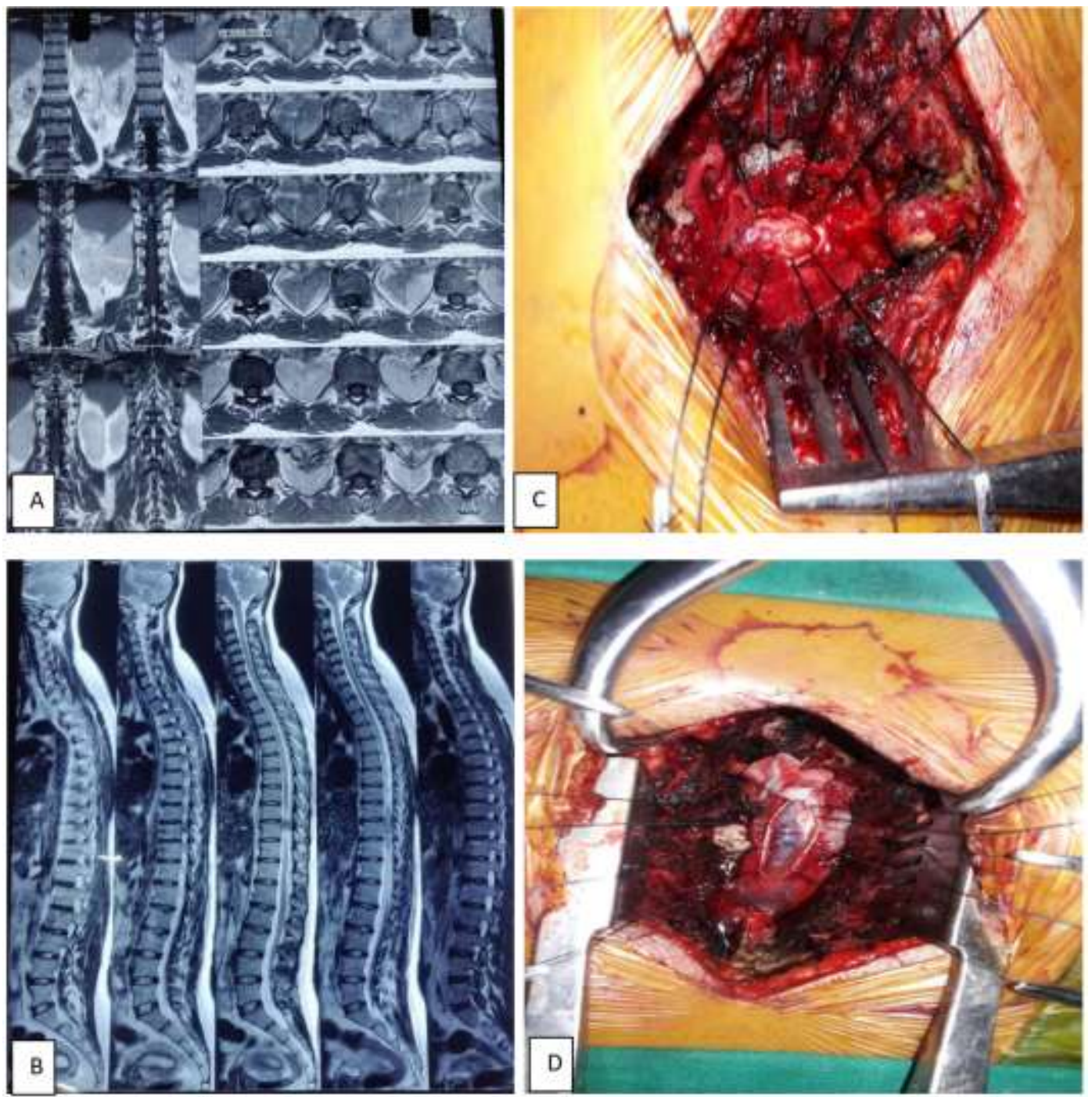

Fig A,B: MRI Dorso-Lumbar spine showing intensely enhancing Intradural extramedullary focal lesion on left side of spinal canal at D9-10 level compressing/ displacing the cord with cord edema. Fig C,D: Before and after removal of tumor surgically
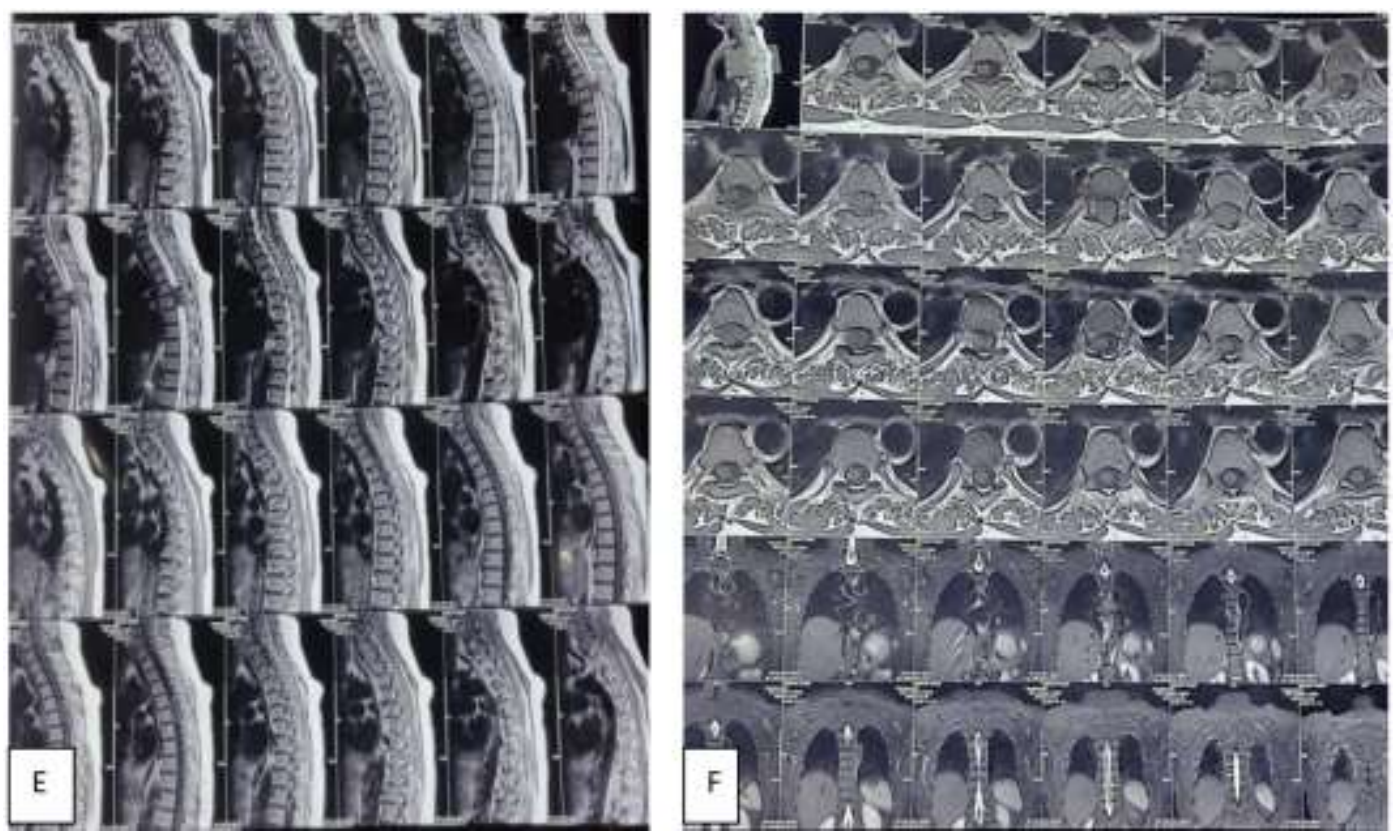

Fig E,F: MRI Dorso-lumbar spine shows well defined homogenously enhancing intradural extramedullary lesion in left lateral thecal sac at D4/D5 level with dural enhancement, causing right-wards displacement and compression of the cord with edema from D3 to D7 levels 


\section{DISCUSSION}

Familial nervous system cancers are rare and limited data on familial aspects are available particularly on site-specific tumours. Studies have been conducted to analyse familial risks of nervous system tumors using standardized incidence ratios.

Standardised incidence ratios (SIRs) are calculated for offspring of affected relatives compared with offspring of non-affected relatives. Standardised incidence ratios (SIRs) are used to measure the cancer risks for offspring according to occurrence of cancers in their families [12]. According to the study, standardised incidence ratios were calculated for offspring whose parent, sibling or parent and sibling had the same, concordant cancer, that is using parents or sibling as probands. The SIR of brain tumours was 1.7 in offspring of affected parents; it was 2.0 in siblings and 9.4 in families with a parent and sibling affected. For spinal tumours, the SIRs were much higher for offspring of early onset tumours, 14.0 for offspring of affected parents and 22.7 for siblings. The SIRs for peripheral nerve tumours were 16.3 in offspring of affected parents, 27.7 in siblings and 943.9 in multiplex families. Brain cancer accounted for $87.6 \%$ of all offspring cases and $93.7 \%$ of the familial cases, spinal tumours accounted for $6.7 \%$ of all and $1.3 \%$ of the familial cases, peripheral tumours accounted for $5.7 \%$ of all and $6.0 \%$ of the familial cases. The early onset cases were a minority of all cases at each anatomic site but among familial spinal and peripheral nerve patients they were the majority. For concordant anatomic sites, peripheral nerves showed the highest risk, followed by the spine and the brain.

\section{CONCLUSION}

Some $90 \%$ of nervous system tumours are located in the brain whereas spinal and peripheral nerve tumours account for the remainder [13]. Recently large epidemiological studies on nervous system cancer have been carried out but a few environmental risk factors have consistently been identified [14]. Therapeutic and low-level irradiation, hereditary syndromes and family history remain as the established risk factors of nervous system tumours [15-18]. Less than $3 \%$ of patients with nervous system tumours have a first-degree family member diagnosed by these neoplasms [18]. Because of the low incidence and rarity of familial cancers many of the published genetic epidemiological studies have not been able to distinguish anatomic locations or tumour types with sufficient numbers of cases [19-21]. But some studies have shown a promising relation of familial spinal cancers especially meningiomas.

\section{REFERENCES}

1. Albanese V, Platania N. Spinal intradural extramedullary tumors. Personal experience; J Neurosurg Sci. 2002, 46:18-24
2. Gezen F, Kahraman S, Canakci Z. Review of 36 cases of spinal cord meningioma. Spine 2000, 25:727-731.

3. Cohen-Gadol AA, Zikel OM, Koch CA. Spinal meningiomas in patients younger than 50 years of age: a 21-year experience, J Neurosurg (Spine). 2003, 98:258-263.

4. Gottfried ON, Gluf W, Quinones-Hinojosa A, Kan P, Schmidt MH. Spinal meningiomas: surgical management and outcome. Neurosurgical focus. 2003 Jun 1;14(6):1-7.

5. Morandi X, Haegelen C, Riffaud L, Amlashi S, Adn M, Brassier G. Results in the operative treatment of elderly patients with spinal meningiomas. Spine. 2004 Oct 1;29(19):2191-4.

6. De Verdelhan O, Haegelen C, Carsin-Nicol B, Riffaud L, Amlashi SF, Brassier G, Carsin M, Morandi X. MR imaging features of spinal schwannomas and meningiomas. Journal of neuroradiology. 2005 Jan 1;32(1):42-9.

7. Haegelen C, Morandi X, Riffaud L, Amlashi SF, Leray E, Brassier G. Results of spinal meningioma surgery in patients with severe preoperative neurological deficits. European Spine Journal. 2005 Jun 1;14(5):440-4.

8. Cavanaugh DA, Jawahar A, Lee JA, Wilkinson K, Kerr III EJ, Nunley PD. Intraspinal meningioma in a 101-year old: should age determine the aggressiveness of intervention? Surgical neurology. 2008 Feb 1;69(2):130-4.

9. Riad H, Knafo S, Segnarbieux F, Lonjon N. Spinal meningiomas: surgical outcome and literature review. Neurochirurgie. 2013 Feb 1;59(1):30-4.

10. Achari G, Behari S, Mishra A, Pandey R, Jain VK. Extradural meningioma en-plaque of the cervical cord. Neurological research. 2000 Jun 1;22(4):351-3

11. Caroli E, Acqui M, Roperto R, Ferrante L, D'Andrea G. Spinal en plaque meningiomas: a contemporary experience. Neurosurgery. 2004 Dec 1;55(6):1275-9.

12. Hemminki K, Tretli S, Olsen JH, Tryggvadottir L, Pukkala E, Sundquist J, Granström C. Familial risks in nervous system tumours: joint Nordic study. British journal of cancer. 2010 Jun;102(12):1786-90.

13. Centre for Epidemiology. Cancer Incidence in Sweden 2005. The National Board of Health and Welfare: Stockholm. 2007.

14. Bondy ML, Scheurer ME, Malmer B, BarnholtzSloan JS, Davis FG, Il'yasova D, Kruchko C, McCarthy BJ, Rajaraman P, Schwartzbaum JA, Sadetzki S, Schlehofer B, Tihan T, Wiemels JL, Wrensch M, Buffler PA (2008) Brain tumour epidemiology: consensus from the Brain Tumour Epidemiology Consortium. Cancer. 2008; 113: 1953-1968.

15. Stewart B, Kleihues P. (eds). World Cancer Report. IARC Press: Lyon. 2003. 
16. Hijiya N, Hudson MM, Lensing S, Zacher M, Onciu M, Behm FG, Razzouk BI, Ribeiro RC, Rubnitz JE, Sandlund JT, Rivera GK, Evans WE, Relling MV, Pui CH. Cumulative incidence of secondary neoplasms as a first event after childhood acute lymphoblastic leukemia. JAMA. 2007; 297:1207-1215.

17. Maule M, Scelo G, Pastore G, Brennan P, Hemminki K, Tracey E, Sankila R, Weiderpass E, Olsen JH, McBride ML, Brewster DH, PompeKirn V, Kliewer EV, Chia KS, Tonita JM, Martos C, Jonasson JG, Merletti F, Boffetta P. Risk of second malignant neoplasms after childhood leukemia and lymphoma: an international study. J Natl Cancer Inst. 2007; 99: 790-800.
18. Hemminki K, Sundquist J, Lorenzo Bermejo J. How common is familial cancer. Ann Oncol. 2008; 19:163-167.

19. Goldgar DE, Easton DF, Cannon-Albright LA, Skolnick MH. Systematic population-based assessment of cancer risk in first-degree relatives of cancer probands. J Natl Cancer Inst. 1994; 86: 1600-1607.

20. Hemminki K, Vaittinen P, Kyyrönen P. Agespecific familial risks in common cancers of the offspring. Int J Cancer. 1998; 78: 172-175.

21. Blumenthal DT, Cannon-Albright LA. Familiality in brain tumours. Neurology. 2008; 71: 10151020 . 